\title{
SOSIALISASI MEDIASI SEBAGAI ALTERNATIF PENYELESAIAN SENGKETA MASYARAKAT DI KECAMATAN ANDIR, BANDUNG
}

\author{
Mia Hadiati ${ }^{1}$, Indah Siti Aprilia ${ }^{2}$, dan Gracia Kamarov ${ }^{3}$ \\ ${ }^{1}$ Fakultas Hukum, Universitas Tarumanagara Jakarta \\ Email: miah@fh.untar.ac.id \\ ${ }^{2}$ Fakultas Hukum, Universitas Indonesia \\ Email: indah.siti01@ui.ac.id \\ ${ }^{3}$ Fakultas Hukum, Universitas Tarumanagara Jakarta \\ Email: gracia.205190138@stu.untar.ac.id
}

\begin{abstract}
Mediation is one way of resolving dispute through negotiation or consensus of the partiees with third parties, namely by mediators who are not entitled to impose or decide disputes. The hallmark of the mediation proces is that the negotiation is the same as the deliberation or consensus process, so there should not be an element of coercion to reject or accept an idea for a settlement during the mediation process. Everything must be approved by the partie. The legal basis and background of mediation, the implementation of Mediation in Court is the Regulation of the Supreme Court of the Republic of Indonesia No. 1 of 2016 concerning Mediation Procedures in Courts. The socialization method used is lecture and question and answer. The Research Team in collaboration with Andir District will organize a Mediation Socialization activity as an Alternative for Dispute Resolution in the Community. This mediation socialization is very beneficial for parties or individuals involved in the dispute process, both as disputing parties, mediators / mediators and advisors, such as the Camat, Lurah, Village Apparatus, families, traditional leaders, community leaders, and other parties who to deepen understanding in the field of negotiation and mediation.
\end{abstract}

Keywords: Socialization, Mediation, Alternative Dispute Resolution

\begin{abstract}
ABSTRAK
Mediasi merupakan salah satu cara penyelesaian sengketa melalui perundingana atau mufakat para pihak dengan pihak ketiga yaitu oleh Mediator yang tidak berhak untuk memaksakan atau memutuskan sengketa. Ciri khas proses mediasi adalah perundingannya sama dengan proses musawarah atau konsensus, maka tidak boleh ada unsur pemaksaan untuk menolak atau menerima suatu ide penyelesaian selama proses mediasi berlangsung. Segala sesuatunya harus memperoleh persetujuan dari kedua belah pihak.. Dasar hukum dan latar belakang mediasi pelaksanaan Mediasi di Pengadilan adalah Peraturan makhamah Agung RI No. 1 Tahun 2016 tentang Prosedur Mediasi di Pengadilan. Metode Sosialisi yang dilakukan adalah ceramah dan tanyajawab.Tim Peneliti bekerjasama dengan Kecamatan Andir akan menyelenggarakan kegiatan Sosialisasi Mediasi sebagai Alternatif Penyelesaian Sengketa di Masyarakat. Sosialisasi Mediasi ini sangat bermanfaat bagi pihak atau individu yang terlibat dalam proses sengketa, baik sebagai para pihak yang bersengketa, penengah / mediator maupun pemberi jalan keluar seperti Camat, Lurah, Perangkat Desa, keluarga, ketua adat, Tokoh Masyarakat, dan berbagai lapisan masyarakat untuk mendalami pemahaman di bidang negosiasi dan mediasi.
\end{abstract}

Kata kunci: sosialisasi, mediasi, alternatif penyelesaian sengketa

\section{PENDAHULUAN}

Dalam lingkup pemerintahan dan negara maupun dalam lingkup lingkungan masyarakat, keluarga dan diri sendiri akan selalu muncul konflik. Hal ini dikarenakan manusia adalah sebagai makhluk social tentu berinteraksi dengan sesame, tentu membutuhkan orang lain. Oleh karenanya, manusia tentunya memiliki fungsi untuk berinteraksi satu sama lain untuk memenuhi kebutuhan hidupnya. Dalam berbagai interaksi yang dilakukan terkadang muncul konflik yang diakibatkan kesalahan pemahaman atau pandangan antara satu individu dengan individu lainnya. Konflik dikenal dalam Bahasa Latin configure yang artinya saling memukul dan kemudian diadaptasi menjadi kata konflik di Indonesia. Pada prespektif sosiologis, konflik adalah sebuah prosess sosial antara dua orang atau lebih, atau antara kelompok maupun antara individu dan kelompok di mana salah satu pihak berusaha ingin memenangkan sengketa dengan membuat 
pihak lain tidak berdaya atau menghancurkannya. Jikalau koonflik yang tidak tertangani maka dapat menyebabkan terjadinya gap atau kesenjangan dalam masyarakat berupa kesenjangan social, ekonomi maupun Pendidikan kerapkali menimbulkan pergesekan dalam sebuah kepentingan dalam masyarakat sehingga dapat timbul perpecahan dan perselisihan ditengah masyarakat . Kemudian hukum muncul untuk mengakomodasi berbagai permasalahan yang timbul di dalam kehidupan manusia, baik sebagai pencegah konflik dan penyelesai konflik.

Terdapat berbagai macam penyelesaian sengketa yang dikenal di masyarakat. Pada umumnya, masyarakat akan mengajukan permasalahannya ke Pengadilan melalui jalur litigasi. Penyelesaian sengketa melalui pengadilan adalah model yang paling umum dan paling banyak digunakan masyarakat untuk menyelesaikan suatu sengketa. Namun disadari proses sengketa lewat Pengadilan kerapkali membutuhkan waktu yang lama dan juga biaya yang dikeluarkan tidak sedikit. Hal ini diakibatkan oleh banyaknya kasus yang diterima, diperiksa, dan diadili oleh Pengadilan sangatlah banyak, sehingga menyebabkan kurang efektif dan efisiennya penyelesaian. sengketa di Pengadilan. Penyelesaian sengketa melalui jalur litigasi juga berpotensi mengeruhkan keadaan karena prosesnya yang cenderung lama, serta hasil putusannya cenderung memenangkan satu pihak dan mengalahkan pihak yang lainnya (win-lose solution).

Demi mewujudkan penyelesaian sengekta yang efektif telah ditemukan berbagai bentuk penyelesaian sengketa yang lain. Bentuk penyelesaian perselisihan sengketa yang dianggap lebih efektif dan efisien untuk dapat mempercepat proses penyelesaian ini terdapat diluar pengadilan dikenal dengan nama Alternative Dispute Resolution (ADR) atau Alternatif Penyelesaian Sengketa (APS). ADR memiliki beberapa bentuk seperti negosiasi, arbitrase, mediasi dan lain sebagainya. ADR pertama kali berkembang di Amerika. ADR atau APS sering diartikan dengan istilah alternatif to litigation namun sering kali juga diartikan sebagai alternativ to adjudication. ADR mempunyai daya tarik khusus di Indonesia karena keserasian dengan sistem sosial-budaya trasdisional yang berdasarkan musyawarah mufakat. Beberapa keuntungan yang sering muncul di dalam ADR diantaranya adalah prosedur yang cepat, hemat waktu, hemat biaya, itikad baik antara masing pihak, dan berbagai keuntungan lainnya.

Alternative Dispute Resolution (ADR) kerapkali diartikan sebagai alternative to litigation namun juga beberapa masyarakat menyebut dengan alternative to adjudication. Dua pengertian terhadap salah satu pemilihan tersebut mengakibatkan timbulnya implikasi yang berbeda. Pengertian pertama menjadi acuan (alternative to litigaation), termasuk arbitrase yang merupakan bagian dari ADR maka seluruh mekanisme penyelesaian sengketa dilakukan di luar pengadilan. Pengertian kedua, jikalau ADR (di luar litigasi dan arbitrase) termasuk bagian dari ADR, sehingga dapat disimpulkan bahwa pengertian ADR/APS sebagai alternativ to adjudicaation dapat juga meliputi negosiasi, mediasi dan konsiliasi yang merupakan mekanisme penyelesaian sengketa yang bersifat konsensual, consensus, atau kooperatif. Terdapat berbagai macam alternatif penyelesaian sengketa yang kini dapat digunakan oleh masyarakat guna mencari penyelesaian terhadap sengketa yang dihadapi. Salah satunya adalah Mediasi. Mediasi dipandang memiliki efektivitas yang tinggi dalam menyelesaikan sengketa masyarakat, serta memiliki banyak manfaat dan keuntungan. Mediasi adalah sebuah cara penyelesaian dengan mekanismenya melalui cara proses perundingan antara para pihak yang kemudian dilaksanakan untuk memperoleh kesepakatan antar para pihak dengan dibantu oleh pihak ketiga, yang dalam hal ini adalah mediator.

Mediasi bukanlah sesuatu hal yang baru didengar di Indonesia, Indonesia sendiri telah lama menerapkan sistem penyelesaian sengketa melalui Mediasi. Di masyarakat lumrah disebut dengan istilah musyawarah untuk mufakat. Masyarakaat biasanya akan melakukan pemilihan dan menempatkan tokoh-tokoh seperti tokoh adat, tokoh agama atau tokoh masyarakat yang mempunyai wibawa dan mereka yang dapat dipercayai sebagai Mediator untuk membantu menjadi penengah dalam menyelesaikan sengketa yang ada di masyarakat. Salah satu penerapan 
Mediasi sebagai cara dalam menyelesaikan sengketa telah sesuai dengan nilai filosofis Bangsa Indonesia yaitu Pancasila. Pada sejarah peradilan di Indonesia juga terdapat sebuah proses penyelesaian sengketa yang mirip dengan Mediasi yaitu berupa upaya damai yang harus ditempun oleh Hakim dalam memeriksa, mengadili dan memutus perkara perdata. Ketentuan yang mengatur upaya damai diatur dalam Pasal $130 \mathrm{HIR} / 154 \mathrm{RBg}$.

Kewajiban dalam menempuh proses acara mediasi di lembaga peradilan sudah diberlakukan dan diintegrasikan dalam sistem beracara di pengadilan sejak lahirnya Peraturan Mahkamah Agung RI Nomor 1 Tahun 2008. Proses mediasi tersebut terus melakukan perbaikan sistem dalam implementasinya yang kemudian lahir Peraturan Mahkamah Agung RI Nomor 1 Tahun 2016 tentang Prosedur Mediasi di Pengadilan sebagai pengganti Peraturan Mahkamah Agung sebelumnya. Manfaat jalur mediasi dalam menyelesaikan sengketa sangat bermanfaat, karena para pihak dapat meraih kesepakatan yang mengakhiri persengketaan para pihak dengan saling menguntungkan dan adil. Sekalipun proses mediasi yang dijalankan gagal dan para pihak belum mencapai kesepakatan, sebenarnya juga manfaat mediasi telah dirasakan. Jika para pihak bersedia bertemu dalam suatu proses mediasi, setidaknya para pihak telah mampu mengklarifikasikan akar persengketaan dan mempersempit perselisihan di antara mereka.

Keterlibatan keberadaann pihak ketiga (baik perorangan maupun dalam bentuk suatu lembaga independen) dalam proses mediasi bersifat netral dan tidak memihak, yang berfungsi sebagai mediator. Peranan pihak ketiga haruslah netral, independen, tidak memihak dan di tunjuk oleh para pihak. Pihak ketiga yang disebut sebagai mediator memiliki kewajiban untuk melaksanakan tugas dan fungsinya berdasarkan keputusan,kemauan dan kehendak para pihak. Pertemuan secara terpisah dengan para pihak tujuannya adalah para pihak dapat lebih meyakinkan pihak yang lemah adalah posisi mereka, sehingga mediator dapat berupaya mengatasinya melalui pendekatan dan saran yang dapat melancarkan proses penyelesaian sengketa. Peranan keahlian dan proses mediasi menjadi sangatlah penting dalam berkaitan erat dengan pencegahan dan penyalahgunaan kekuasaan kekuasaan.

Mediasi dapat memberi berbagai manfaat seperti:

1) Menyelesaikan sengketa secara cepat dan murah dibanding ke Pengadilan atau lembaga arbitrase.

2) Mediasi tidak hanya berfokus pada hak-hak hukum, akan tetapi kepada kepentingan para pihak secara nyata dan kebutuhan emosi juga.

3) Para pihak dapat berpartisipasi secara langsung maupun secara informal.

4) Para pihak diberi kemampuan untuk mengontrol proses dan hasilnya.

5) Mediasi memberikan hasil yang diharapkan tahan uji dan memberi pemahaman yang lebih baik antar para pihak sendirilah yang menentukan hasil akhirnya

6) Mediasi mampu menghilangkan konflik atau permusuhan yang kerapkali muncul dalam sebuah proses perselisihan mekanisme litigasi.

Perkara yang dapat diselesaikan secara damai oleh mediator, harus dilaporkan kepada Ketua Majelis. Akan tetapi, memang mediasi ini sudah menjadi keharusan dan kewajiban yang harus dilakukan oleh perkara-perkara perdata seabagimana diamanatkan dalam Peraturan Mahakamh Agung Nomor 1 Tahun 2016. Perkara-perkara perdata tersebut biasanya merupakan perkara yang sifatnya perseorangan seperti perceraian.

Mediasi merupakan sebuah bentuk lain dari alternatif penyelesaian sengketa di luar pengadilan. Mediasi menyelesaikan sengketa antara para pihak dengan batuan dari pihak ketiga yang tidak bias dan netral. Mediasi dapat menghasilkan perdamaian yang permanen dan lestari antar pihak. Dalam mediasi tidak ada pihak yang menang atau pihak yang dikalahkan (win-win solution).

Proses penyelesaian sengketa melalui mediasi memberikan efek yang signifikan dalam praktik, manfaat menyelsaiakan melalui mediasi secara teori relatif efektif dibandingkan dibanding proses pengadilan, karena dapat mengevaluasi kasus secara potensial. Namun dalam mengkaji 
suatu efektivitas sistem hukum sendiri, dalam penelitian ini peneliti menggunakan teori Efektivitas hukum yang dikemukakan oleh Prof. Soerjono Soekanto. Menurutnya terdapat beberapa faktor pendukung efektivitas yaitu Undang-undang atau regulasi, sarana dan fasilitas yang mendukung penggerakan hukum, serta masyarakat dan kebudayaan yang berkembang.

Pertama secara normatif ketiga faktor pendukung efektivitas tersebut sudah ada diantaranya Undang-Undang atau regulasi hukum yakni adanya Peraturan Mahkamah Agung Number. 1 Thn 2008 yang diubah dengan Peraturan Makhamah Agung Nomor.1 Thn 2016. Dalam Peraturan Makhamah Agung Nomor. 1 Thn 2016 dinyatakan bahwa Mediasi merupakan sebuah cara penyelesaian sengketa dengan proses tawar-menawar untuk mendapatkan kesepakatan tujuan yang sama antar pihak yang dipimpin oleh Mediator atau pihak ketiga yang membantu menyelesaikan proses tersebut. Mediasi sebagai upaya perdamaian antar berperkara diwajibkan dilakukan dalam peradilan di Indonesia sebelum perkaranya diperiksa. Upaya ini dilakukan agar mencapai titik temu menyelsaikan permasalahan kedua belah pihak tersebut. Mediasi ini dapat menjembatani para pihak untuk para pihak agar tercapai solusi yang terbaik bagi para pihak.

Kedua adalah fasilitas yang mendukung, di Kelurahan Maleber tersedia ruangan ruangan aula yang dapat dijadikan sebagai ruang mediasi. Perangkat Kelurahan seperti Lurah, Sekretaris Lurah, dan Pegawai Kelurahan laiinya dapat menjadi fasilitator dan juga mediator dalam menangani konflik/sengketa di masyarakat. Diadakannya sosilasisi ini bertujuan untuk memberikan pembekalan kepada perangkat, tokoh masyarakat, dan masyarakat itu sendiri dalam memfasilitasi penanggulangan sengketa melalui mediasi.

Ketiga adalah kepatuhan dan kebudayaan masyarakat. Sifat mediasi yang mengambil nilai musyawarah untuk mufakat menjadi faktor utama efektifnya mediasi dalam menyelesaikan konflik/sengeketa di masyarakat.

Melalui mediasi di dalam masyarakat, setidaknya masalah dapat diredam sebelum membesar dan meluas. Perangkat Kelurahan/Kecamatan atau tokoh masyarakat dapat menjadi garda terdepan dalam menangani sengketa/konflik di berbagai forum penyelesaian sengketa, mediasi mengandalkan pada penyelesaian secara musyawarah dan dilakukan secara fleksibel. Karena itu penyelesaian yang adil dapat lebih mudah diterima oleh para pihak yang sedang berselisih karena hasilnya dapat dikembalikan pada kehendak masing-masing pihak karena para pihak dilibatkan secara aktif dalam penyelesaian sengketanya. Forum mediasi akan memberikan luaran atau hasil yang disepakaati oleh para pihak yang terlibat dalam konflik dengan meminimalisir kerugian masing - masing pihak.

Berhubungan dengan hal-hal yang telah dipaparkan sebelumnya, dipandang diperlukan adanya suatu tim yang melakukan sosialisasi dan memperkenalkan mediasi terhadap masyarakat di Kecamatan Andir, Bandung agar masyarakat dapat mengetahui penyelesaian sengketa yang dapat dilakukan melalui mediasi, sekaligus menjadi pelopor dalam menanggulangi konflik/sengketa di daerah tempat tinggalnya masing-masing. Tim Pengusul bekerjasama dengan Kecamatan Andir, Kota Bandung akan menyelenggarakan kegiatan Sosialisasi Mediasi sebagai Alternatif Penyelesaian Sengketa di Masyarakat. Kegiatan sosialisasi ini akan dilakukan berupa untuk memberikan pengetahuan hukum, informasi terkini, aturan hukum, dokumen, konsultasi hukum, dan isu-isu yang berkembanga dalam masyarakat untuk dikaji dan dipahami bersama.

\section{METODE PELAKSANAAN PKM}

\section{Langkah-langkah/tahapan pelaksanaan}

Kegiatan sosialisasi sosialisasi tentang Penanggulangan Perkawinan Usia di Bawah Umur di Kecamatan Andir, Bandung mengikuti prinsip-prinsip keterbukaan, partisipasi, koordinasi, dan keterpaduan. S Sosialisasi Mediasi Sebagai Alternatif dalam Menyelesaikan Sengketa Masyarakat di Kecamatan Andir, Bandung harus mampu menguraikan berbagai aspek penting mengenai mediasi, kelebihan mediasi, tata cara menjadi mediator, serta berbagai ketentuan 
teknis lainnya. Metode sosialiasi berupa presentasi materi seperti sosialisasi dan diskusi dua arah aktif antara masyarakat dengan pemateri sosialisasi.

\section{Partisipasi mitra dalam kegiatan PKM}

Kecamatan Andir, Kota Bandung sebagai mitra dalam kegiatan PKM akan membantu tim dalam memfasilitasi tempat dan sarana, serta menyebarkan informasi mengenai sosialisasi yang diadakan. Mitra juga akan menugaskan perangkat kecamatan untuk mengikuti sosialisasi ini.

\section{Uraian kepakaran dan tugas massing-masing anggota tim}

Materi yang akan disampaikan pada sosialisasi ini antara lain:

1. Pengantar Mediasi oleh Mia Hadiati, S.H., M.H.

2. Kelebihan dan Keuntungan Mediasi oleh Indah Siti Aprilia, S.H.

3. Proses Mediasi dalam Masyarakat oleh Gracia Kamarov

\section{HASIL DAN PEMBAHASAN}

Sosialisasi ini dilaksanakan pada tanggal 21 September 2021 di Kecamatan Andir, Bandung. Pelaksanaan dilakukan pada pkul. 13.00-16.00 WIB. Terdapat audiens penting yang hadir dalam sosialisasi ini seperti : Camat, Lurah, Perangkat Desa, keluarga, ketua adat, Tokoh Masyarakat di lingkungan Kecamatan Andir, Bandung. Hal - hal yang didapatkan dalam kegiatan sosialisasi ini adalah masyarakat tidak mengetahui bahwa sengketa dapat menjadi alternatif penyelesaian sengketa, masyarakat hanya mengetahui sengketa dapat diselesaikan dengan vonis hakim atau di pengadilan, selain itu masyarakat juga menyampaikan pendapat bahwa pemerintah kurang mengedukasi dan mensosialisasikan tentang mediasi yang mengakibatkan ketidaktahuan di masyarakat. Dalam kegiatan sosialisasi ini, kami selaku tim dari FH UNTAR memberikan edukasi, pengetahuan tentang mediasi sebagai salah satu jalan keluar permasalahan sengketa.

Pertama-tama pembahasan dimulai dengan membahas mengenai definisi dan bentuk nyata mediasi dalam kegiatan sehari-hari. Bahwa pada hakikatnya mediasi dilakukan antara pihak berkepentingan dengan melibatkan pihak ketiga untuk mencapai kesepakatan yang bersifat kompromi. Pihak ketiga ini bisa berasal dari tokoh adat, maupun tokoh masyarakat yang ada di daerah masing-masing. Pembahasan yang sangat mendapat antusias dari masyarakat adalah pada saat pembahasan mengenai langkah-langkah mediasi serta manfaat dari mediasi yang ternyata mediasi jauh lebih mudah dan menghasilkan efek positif dibandingkan penyelesaian melalui jalur litigasi maupun main hakim sendiri, yakni seperti bahwa mediasi sangat memungkinkan kedua para pihak untuk mencapai win-win solution atau kesepakatan yang adil dan merata dan disetujui oleh para pihak dimana para pihak tidak ada dimenangkan dan tidak ada pihak yang dikalahkan sehingga kepentingan kedua belah pihak dapat terakomodir, selain itu pelaksanaan mediasi juga relative singkat dan sederhana yang menunjukan mediasi sebagai jawaban ketidakpuasan atas sistem proses pengadilan yang lambat, termakannya waktu, biaya, kemampuan untuk menangani kasus. Beberapa pertanyaanpun diajukan oleh masyarakat, salah satu contohnya yakni mengenai solusi apabila salah satu pihak tidak melaksanakan hasil mediasi yang ditetapkan bersama, lalu ada juga pertanyaan mengenai bagaimana cara untuk menjamin hasil mediasi akan dilaksanakan. Salah satu kekhawatiran mereka yang terbesar yakni apabila salah satu pihak ternyata tidak tunduk pada hasil mediasi. Pertanyaan-pertanyaan itu dijawab dengan baik oleh Tim FH Untar melalui jawaban yang sederhana dan mudah diterima masyarakat. 
Melalui sosialisasi ini, tokoh penting seperti Camat, Lurah, Perangkat Desa, Ketua Adat, dan Tokoh Masyarakat dapat mensosialisasikan kepada masyarakat pelosok yang tidak memiliki akses informasi, pengetahuan yang minim tentang hukum. Melalui sosialisasi ini, kami memberikan informasi dan pengetahuan terkait Yang terahir adalah masyarakat mengharapkan bahwa kegiatan sosialisasi ini dapat memberikan hasil yang sesuai dan nyata dilingkungan Kecamatan Andir, Bandung. Para peserta yang mengikuti sosialisasi ini menjadi memiliki misi penting untuk menyampaikan kembali ke masyarakat sesuai dengan informasi yang telah didapatkan dari sosialisasi ini. Tokoh penting di Kecamatan Andirakan mengatur pertemuan kembali kepada Tim FH UNTAR untuk mendapatkan konsultasi hukum, masukan dan feedback. Kami selaku Tim FH UNTAR telah memberikan masukan yang akan menjadi catatan bagi tokoh penting di Kecamatan Andir, Bandung.

Apresiasi juga disampaikan oleh Camat serta tokoh masyarakat di Kecamatan Andir, Bandung yang telah dilaksanakan oleh Tim FH UNTAR. Camat juga berpendapat bahwa masyarakat menjadi "melek" hukum, dan mengetahui penyelesaian sengketa dapat dilakukan diluar pengadilan yaitu melalui mediasi. Adanya sosialisasi yang diadakan oleh Tim FH UNTAR dan Kecamatan Andir telah memberikan informasi dan edukasi kepada masyarakat di Kecamatan Andir mengenai mediasi. Masyarakat yang menjadi peserta sosialisasi telah menjadi agen perubahan untuk lingkungannya dan menjadi garda terdepan dalam menyelesaikan sengketa sebaik mungkin melalui adanya mediasi terutama di lingkungan Kecamatan Andir, Bandung.

\section{KESIMPULAN DAN SARAN}

\section{Kesimpulan}

Berdasarkan kegiataan yang telah terlaksana maka dapat kami simpulkan bahwa bahwa pengetahuan tentang penyelesaian sengketa melalui mediasi jarang diketahui oleh masyarakat terutama pada masyarakat yang memiliki pendidikan yang rendah . Maka kegiatan sosialisasi ini perlu diadakan untuk memberikan pengetahuan tentang cara penyelesaian sengketa melalui mediasi, peran dan tujuan mediasi, serta apa dampak dan hasil dari mediasi.

Sosialisasi ini dilakukan dengan menggunakan penyampaian melalui metode pemaparan materi dan tanya jawab,diskusi konsultasi hukum serta team building. Pemaparan materi adalah penyampaian yang dilakukan dengan menggunakan metode tanya jawab sesuai dengan keahlian di bidang masing-masing. Metode tanya jawab adalah metode yang dilakukan kepada masyarakat yang mengikuti sosialisasi ini untuk menanyakan hal-hal yang kurang dipahami dengan bentuk konsultasi / bantuan hukum secara Cuma-Cuma kepada masyarakat . Begitu banyaknya antusias dari masyarakat mengenai sosialisasi dan kegiatan iin, masyrakat mengharapkan untuk memberikan materi lanjutan . Penyelenggaraan acara ini termasuk dalam kategori tidak terdapat kendala, baik dalam hal administrasi maupun dalam pelaksanaan sosialisasi.

\section{Saran}

Saran kami adalah yang terutama agar pemerintah dapat melaksanakan sosialisasi kepada masyarakat agar mengetahui penyelesaian sengketa tidak hanya melalui pengadilan atau dihakimi warga, tetapi dapat menggunakan jalur mediasi. Pemerintah serta peserta sosialisasijuga dapat memberikan edukasi dan pemahaman mengenai mediasi kepada masyarakat.

\section{Ucapan Terima Kasih (Acknowledgement)}

Ucapan terima kasih sampaikan kepada LPPM UNTAR khussnya dalam Bidan ABDIMAS yang telah mendukung kami untuk dapat merealisasikan sosialisasi ini. Apresiasi juga kami sampaikan kepada masyarakat Kecamatan Andir yang telah menegikuti sosialisasi dengan baik dan antusiasme yang tinggi. Terakhir, kami ucapkan terimakasih kepada Bapak Camat 


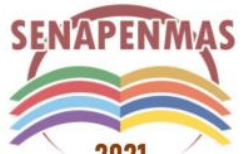

2021
Seminar Nasional Hasil Penelitian dan Pengabdian Kepada Masyarakat 2021 Pengembangan Ekonomi Bangsa Melalui Inovasi Digital Hasil Penelitian dan Pengabdian Kepada Masyarakat Jakarta, 21 Oktober 2021

Kecamatan Andir, Tokoh Adat, Tokoh Agama dan PKK Kecamatan Andir atas partisipasi aktif dan keikutsertaannya dalam sosialisasi yang telah dilaksanakan dengan tema sosaialisasi Mediasi Saebagai Alternatif Penyelesaian Sengketa Masyarakat Di Kecaamatan Andir, Bandung.

\section{REFERENSI}

Kabeshian,.Lyn A. (1994). ADR: To BE or...? North Dakota Law Review.

Margonoo, Suyud. (2010). Penyelesaian Sengketa Bisnis Alternative Dispute.Resolutin (ADR) Tekniik dan Strategis Negosiasi, Mediasi dan Arbitrase). Bogor: Penerbit Ghalia.

Moore, Christopher W. (1995). (CDR Associate).

Widjaja, Gunawan. (2001). Alternatif.Penyelesaian Sengketa. Jakarta: Rajawalii Press.

Peraturan Makhamah Agung Nomor 1 Tahun 2016

Korah, Revy S.M. (2013). "Mediasi merupakan salah satu alternatif penyelesaian masalah dalam sengketa perdagangan internasional", media neliti, Vol.XXI/No.3/April-Juni/2013, https://www.neliti.com/publications/872/mediasi-merupakan-salah-satu-alternatifpenyelesaian-masalah-dalam-sengketa-perd 
Seminar Nasional Hasil Penelitian dan Pengabdian Kepada Masyarakat 2021

Pengembangan Ekonomi Bangsa Melalui Inovasi Digital Hasil Penelitian dan

Pengabdian Kepada Masyarakat

Jakarta, 21 Oktober 2021

(halaman kosong) 